\title{
PROFIL PNEUMONIA NEONATAL DI SUB BAGIAN NEONATOLOGI BLU RSU PROF. DR. R. D. KANDOU MANADO PERIODE JANUARI 2009-JULI 2011
}

\author{
${ }^{1}$ Cicilia Reisy Amanda Walukow \\ ${ }^{1}$ Kandidat Skripsi Fakultas Kedokteran Universitas Sam Ratulangi Manado \\ ${ }^{2}$ Bagian Ilmu Kesehatan Anak Fakultas Kedokteran Universitas Sam Ratulangi \\ Email:paai_manado@yahoo.com
}

\begin{abstract}
Neonatal pneumonia is a disease of acute respiratory infections (ARI) caused primarily by bacteria and is a significant cause of death in newborns, occurring within the first 30 days of life infants. Infants with uncomplicated pneumonia by blood-borne infections have an increased risk of death was $10 \%$ and the risk became three times if the infants had birth weight. The design in this study was retrospective descriptive. Data was collected from December 2011 to January 2012 used secondary data from patients medical records in subsection of neonatology in Prof. Dr. R. D. Kandou Manado general hospital from January 2009 to July 2011. Conclusion: The results showed that the majority of neonatal pneumonia patients was born in Prof. Dr. R. D. Kandou Manado general hospital with normal deliveries.
\end{abstract}

Key words: neonatal pneumonia, subsection of neonatology, normal delivery.

\begin{abstract}
Abstrak: Pneumonia Neonatal merupakan penyakit infeksi saluran pernapasan akut (ISPA) yang disebabkan terutama oleh bakteri dan merupakan penyebab signifikan kematian pada bayi yang baru lahir, yang terjadi dalam 30 hari pertama kehidupan bayi. Bayi dengan pneumonia yang terkomplikasi oleh infeksi melalui darah memiliki resiko kematian $10 \%$ dan resiko ini menjadi tiga kali lipat jika bayi memiliki berat badan lahir. Desain penelitian ini bersifat deskriptif retrospektif. Pengambilan data dilakukan dari bulan Desember 2011 sampai dengan Januari 2012 dengan menggunakan data sekunder melalui catatan rekam medik pasien yang di rawat di sub bagian neonatologi BLU RSU PROF. DR. R. D. Kandou Manado periode Januari 2009 sampai dengan Juli 2011. Simpulan: Hasil penelitian menunjukkan bahwa yang terkena pneumonia neonatal terbanyak lahir di BLU RSU PROF. DR. R. D. Kandou dengan persalinan normal.
\end{abstract}

Kata Kunci: Pneumonia neonatal, sub bagian neonatologi, persalinan normal.

Pneumonia neonatal merupakan penyakit in-feksi saluran pernapasan akut (ISPA) yang disebabkan terutama oleh bakteri, yang paling sering menyebabkan kematian pada bayi dan anak balita. Bakteri penyebab pneumonia paling sering adalah streptococcus pneumonia (pneumokokus), hemophilus influenza tipe $b$ (Hib) dan staphylococcus aureus. ${ }^{1}$

Pneumonia merupakan penyebab utama kematian di antara semua kelompok umur. Pada anak-anak, banyak dari ke- matian ini terjadi pada masa neonatal. Organisasi Kesehatan Dunia memperkirakan bahwa satu dari tiga kematian bayi baru lahir disebabkan pneumonia, Lebih dari dua juta meninggal setiap tahun di seluruh dunia. $^{2}$

Pneumonia neonatal merupakan penyebab signifikan kematian pada bayi yang baru lahir, yang terjadi dalam 30 hari pertama kehidupan bayi. Bayi dengan pneumonia yang terkomplikasi oleh infeksi melalui darah memiliki resiko kematian 
$10 \%$ dan resiko ini menjadi tiga kali lipat jika bayi memiliki berat badan kurang saat lahir. $^{3}$

Dengan memahami dan mengetahui profil Pneumonia neonatal kita dapat mengurangi angka kematian pada neonatal dan dapat mendiagnosa secara cepat dan tepat, sehingga dapat melakukan pengobatan, dan mencegah komplikasikomplikasi. Dari hal-hal tersebut penulis ingin mengetahui dan mempelajari profil pneumonia neonatal di sub bagian neonatologi BLU RSUP Prof.Dr.R.D Kandou Manado sehingga bisa di lakukan pengobatan yang cepat dan tepat agar tidak terjadi kom-plikasi ataupun kematian.

\section{METODE PENELITIAN}

Penelitian ini dilakukan secara deskriptif retrospektif yang bertujuan untuk mengetahui profil pneumonia neonatal di sub bagian neonatologi BLU RSU Prof. DR. R. D Kandou Manado periode Januari 2009-Juli 2011. Tempat penelitian dilakukan di sub bagian neonatologi bagian Ilmu Kesehatan Anak BLU RSU Prof. DR. R. D. Kandou Manado dan waktu penelitian dilakukan pada Desember 2011Januari 2012. Sampel dari penelitian ini ialah semua data penderita yang terdiagnosa pneumonia neonatal di sub bagian neonatologi yang di ambil dari data rekam medik BLU RSU Prof. DR. R. D Kandou Manado.

Alat dan bahan yang diperlukan dan akan dipakai ialah alat tulis menulis, data rekam medik pada neonatal yang terkena pneumonia dari Januari 2009-Juli 2011, kepustakaan yang berhubungan dengan karya ilmiah ini. Cara kerja yang akan di lakukan yaitu Mengumpulkan data kasus penderita yang telah di diagnosis pneumonia pada neonatal selanjutnya data tersebut akan di kelompokkan berdasarkan variabel penelitian dan disajikan dalam bentuk teks dan tabel. Kemudian dianalisis berdasarkan hasil penelitian. Variabel penelitian yang di ambil penulis ialah Tempat lahir seperti, penolong per- salinan, jenis persalinan,umur kehamilan, nilai apgar menit pertama dan kelima, cara terjadi, keadaan bayi saat keluar dari rumah sakit, jenis kelamin, berat badan lahir, komplikasi yang terjadi seperti sepsis, meninggal, pneumotoraks, kolestasis.

Total data yang diperoleh ialah 100 data pasien dari data rekam medik

Tabel 1. Distribusi penderita pneumonia neonatal menurut tempat lahir

\begin{tabular}{lcc}
\hline Tempat lahir & Jumlah & Presentase(\%) \\
\hline RSU Kandou & 45 & 45 \\
Rumah sakit lain & 34 & 34 \\
Puskesmas & 21 & 21 \\
Total & $\mathbf{1 0 0}$ & $\mathbf{1 0 0}$ \\
\hline
\end{tabular}

Tabel 2. Distribusi penderita menurut penolong persalinan.

\begin{tabular}{lcc}
\hline \multicolumn{3}{l}{ Penolong Persalinan Penderita } \\
\hline Dokter spesialis & 34 & 34 \\
Dokter umum & - & - \\
Residen & 45 & 45 \\
Bidan & 21 & 21 \\
Total & $\mathbf{1 0 0}$ & $\mathbf{1 0 0}$ \\
\hline
\end{tabular}

Tabel 3. Distribusi penderita menurut jenis persalinan.

\begin{tabular}{lrrr}
\hline $\begin{array}{l}\text { Jenis Persalinan } \\
\text { Presentase (\%) }\end{array}$ & & Jumlah & \\
\hline Seksio & 32 & & 32 \\
Spontan & 68 & & 68 \\
Ekstraksi vacuum & - & & - \\
Ekstraksi forsep & - & & - \\
$\quad$ Total & $\mathbf{1 0 0}$ & $\mathbf{1 0 0}$ & \\
\hline
\end{tabular}

Tabel 4 Distribusi penderita menurut apgar score menit ke-1.

\begin{tabular}{lcc}
\hline Apgar Skor $\mathbf{1}$ & Jumlah & Peresntase (\%) \\
\hline $1-3$ & 30 & 33.7 \\
$4-6$ & 36 & 40.5 \\
$7-10$ & 23 & 25.8 \\
Total & $\mathbf{8 9}$ & $\mathbf{1 0 0}$ \\
\hline
\end{tabular}


Tabel 5. Distribusi penderita menurut apgar score menit ke-5.

\begin{tabular}{lcc}
\hline Apgar Score 5 & Jumlah & Presentase (\%) \\
\hline $1-3$ & 23 & 25.8 \\
$4-6$ & 29 & 32.6 \\
$7-10$ & 37 & 41.6 \\
Total & $\mathbf{8 9}$ & $\mathbf{1 0 0}$ \\
\hline
\end{tabular}

Tabel 6. Distribusi penderita menurut penyebab.

\begin{tabular}{llc}
\hline Penyebab & Jumlah & Presentase(\%) \\
\hline Aspirasi meconium & 23 & 23 \\
Sepsis neonatorum & 44 & 44 \\
Prematur & 25 & 25 \\
Postmatur & 7 & 7 \\
GER & 1 & 1 \\
Total & $\mathbf{1 0 0}$ & $\mathbf{1 0 0}$ \\
\hline
\end{tabular}

Tabel 7. Distribusi penderita menurut keadaan penderita saat keluar.

\begin{tabular}{|c|c|c|}
\hline \multicolumn{3}{|c|}{ Keadaan bayi keluar Jumlah Presentase(\%) } \\
\hline Sembuh & 57 & 57 \\
\hline Meninggal & 43 & 43 \\
\hline Total & 100 & 100 \\
\hline
\end{tabular}

Tabel 8. Distribusi penderita berdasarkan jenis kelamin.

\begin{tabular}{ccc}
\hline Jenis Kelamin & Jumlah & Presentase (\%) \\
\hline Laki-laki & 58 & 58 \\
Perempuan & 42 & 42 \\
Total & $\mathbf{1 0 0}$ & $\mathbf{1 0 0}$ \\
\hline
\end{tabular}

Tabel 9. Distribusi penderita menurut berat badan lahir.

\begin{tabular}{ccc}
\hline Berat badan lahir & Jumlah & Presentase(\%) \\
\hline$>4000$ gram & 7 & 7 \\
$2500-3999$ gram & 67 & 67 \\
$1500-2499$ gram & 18 & 18 \\
$1000-1499$ gram & 5 & 5 \\
$<1000$ gram & 3 & 3 \\
Total & $\mathbf{1 0 0}$ & $\mathbf{1 0 0}$ \\
\hline
\end{tabular}

Tabel 10. Distribusi penderita berdasarkan komplikasi yang terjadi.

\begin{tabular}{lcc}
\hline Komplikasi & \multicolumn{2}{c}{ Jumlah Presentase(\%) } \\
\hline Sepsis & 49 & 44.9 \\
Pneumothoraks & 5 & 4.59 \\
Gagal/gawat napas & 31 & 28.4 \\
Meninggal & 16 & 14.7 \\
Kholestasis & 8 & 7.33 \\
Total & $\mathbf{1 0 9}$ & $\mathbf{1 0 0}$ \\
\hline
\end{tabular}

Tabel 11. Distribusi penderita berdasarkan umur kehamilan.

\begin{tabular}{lll}
\hline $\begin{array}{l}\text { Umur Kehamilan } \\
\text { (\%) }\end{array}$ & Jumlah & Presentase \\
\hline Aterm & 68 & 68 \\
Prematur & 25 & 25 \\
Postmatur & 7 & 7 \\
Total & $\mathbf{1 0 0}$ & $\mathbf{1 0 0}$ \\
\hline
\end{tabular}

\section{BAHASAN}

Hasil penelitian menunjukkan bahwa selama periode Januari 2009-Juli 2011 di sub bagian neonatologi Ilmu Kesehatan Anak RSUP Prof. Dr. R. D. Kandou manado dengan 100 sampel penelitian di peroleh pada table 1.1 terbanyak ialah tempat lahir. $45 \%$ lahir di RSUP Prof. Dr. R. D. Kandou manado.

Pada tabel 2, memperlihatkan distribusi penderita berdasarkan penolong persalinan terbanyak dimana penderita yang ditolong oleh residen $45 \%$. Penolong persalinan harus mengetahui dugaan bila ada mekonium dalam cairan amnion sebelum bayi dilahirkan karena penatalaksanaan harus dimulai di kamar bersalin, pada saat kepala keluar harus melakukan pembersihan di daerah orofaring secara adekuat. ${ }^{6}$

Berdasarkan tabel 3 diperoleh bahwa bayi baru lahir dengan pneumonia yang dirawat di sub bagian neonatologi Ilmu Kesehatan Anak RSUP Prof. Dr. R. D. Kandou manado periode Januari 2009-Juli 2011 sebagian besar lahir dengan jenis persalinan spontan $68 \%$, Sesuai dengan teori bahwa persalinan spontan memiliki 
faktor resiko yaitu bayi teraspirasi cairan amnion atau sekresi saluran cerna atau genitourinaria ibu yang terinfeksi saat kelahiran, dan juga persalinan yang lama. ${ }^{4}$

Pada table 4 dan 5 yaitu apgar score menit pertama dan kelima.menit pertama 1-3 (33,7\%), 4-6 (40,5\%), 7-10 (25.8\%), sedangkan menit kelima 1-3 (25,6\%), 4-6 $(32,6 \%), \quad 7-10 \quad(41,6 \%)$, pada menit pertama lebih banyak 4-6 dan pada menit ke-5 lebih banyak 7-10. Dari hasil penelitian tidak semua di dapatkan adanya apgar score, karena ada beberapa yang lahir ditak di lakukan pemeriksaan apgar score.

Pada tabel 6 penyebab dari pneumonia neonatal di peroleh penyebab terbanyak ialah sepsis neonatorum $44 \%$. Hal ini sesuai dengan penelitian Webber $\mathrm{S}$, dkk di rumah sakit John Radcliffe, bahwa $69 \%$ pneumonia disebabkan oleh sepsis neonatorum, karena faktor resiko seperti pecah ketuban lebih dari 18 jam, persalinan spontan, dan juga disebabkan oleh umur kehamilan prematur. ${ }^{5}$

Sedangkan pada tabel 9 menurut berat badan lahir terbanyak ialah 2500-4000 gram $67 \%$. Hal ini sesuai dengan penelitian Eviana ST, di FKM Universitas Indonesia bayi yang memiliki berat badan lebih dari 2500 gram lebih banyak di bandingkan berat badan kurang dari 2500 gram. ${ }^{6}$

Pada tabel 10 menurut komplikasi yang terjadi, paling banyak sepsis yaitu 44,9\%. Dari penelitian didapatkan bahwa pada satu penderita kadang mempunyai dua komplikasi. Menurut teori, pada penyebab aspirasi mekonium komplikasi yang sering terjadi ialah pneumothoraks. Angka kejadiaannya berkisar $15-20 \%$ pada bayi yang tidak memerlukan ventilasi dan sekitar $30-50 \%$ bagi yang memerlukan IPPV. ${ }^{4,7}$

Pada tabel 11 menunjukkan umur kehamilan aterm lebih banyak yaitu $71 \%$. Hal ini berbeda dengan penelitian $\mathrm{S}$. Webber dkk bahwa kehamilan prematur lebih banyak terkena pneumonia di bandingkan umur kehamilan lainnya. Da- lam teori mengatakan pneumonia akibat aspirasi mekonium biasanya lebih sering terjadi pada bayi cukup bulan atau lebih bulan, terutama yang mengalami hambatan pertumbuhan (IUGR). ${ }^{4,8}$

\section{SIMPULAN DAN SARAN}

Tempat lahir mempunyai pengaruh terhadap angka kejadian pneumonia neonatal, karena pengaruh keadaan lingkungan dan bayi laki-laki mempunyai resiko lebih tinggi terserang pneumonia neonatal dari pada bayi perempuan. Jenis persalinan spontan mempunyai pengaruh besar terhadap terjadinya pneumonia pada neonatal, karena banyaknya faktor resiko seperti ketuban pecah dini, infeksi pada jalan lahir maka untuk menghindari terjadinya pneumonia neonatal sebaiknya pada ibu hamil dilakukan pemeriksaan kandungan secara teratur untuk mengontrol keadaan janin dan ibu, dan juga perlu penanganan dini untuk menurunkan angka morbiditas dan mortalitas karena pneumonia neonatal.

\section{DAFTAR PUSTAKA}

1. Misnadiarly. Penyakit infeksi saluran napas. Pneumonia pada anak, orang dewasa, usia lanjut. Edisi 1. Jakarta: Pustaka obor populer; 2008. Hal 26-30

2. Curnow B. Epidemiologi pneumonia.Di unduh dari: www.newsmedical.net/health/pneumoniaepidemiologi(Indonesia).aspx. Di akses tanggal 20 november 2011

3. Emma L. What is pneumonia neonatal?. Diunduh dari http://www.Wisegeek.Com/what-isneonatal-pneumonia.html. Di akses tanggal 16 november 2011

4. Ballrd R, Hansen T, Cobet A. respiratory failure in the term infant. In: Taeusch HW, Ballard RA, Gleason CA, eds. Avery's disease of the newborn, edisi 8. Philadelphia: Elsevier inc, 2005:712-4

5. Webber S. Pneumonia Neonatal.Di unduh dari:http://www.ncbi.nlm.nih.gov/pmc/ articles/PMC1792235/pdf/archdisch00 
110 Jurnal e-Biomedik (eBM), Volume 1, Nomor 1, Maret 2013, hlm. 106-110

665-0059.pdf. John Radcliffe Hospital Oxford, di akses 28 Januari 2012

6. Eviana T. Hubungan berat badan lahir dan infeksi nosokomial diruang perinatologi. FKM Universitas Indonesia. Tahun 2008

7. Lee J, Stark A. Meconium Aspiration. In: Cloherty JP, Eichenwald EC, Stark
AR, eds. Manual of neonatal care, ed 5. Philadhelphia: lippicott Williams and Wilkins, 2004; 204-6

8. Vindeatha. Kholestasis. Di unduh dari: http://vindeatha.wordpress.com/askepanak-dengan-kolestasis. Di akses tanggal 5 januari 2012 